\title{
Good Corporate Governance Islamic Social Responsibility, and Firm Performance
}

\author{
Lela Hindasah, Edi Supriyono
}

\begin{abstract}
This study aims to examine the role of Good Corporate Governance toward financial performance and Islamic Social Responsibility disclosure. The financial performance was measured by Return on Asset (ROA), Return on Equity (ROE), Asset growth, Operating Expenses, and NonPerforming Finance (NPF). Furthermore, this study was carried out by Sharia Bank in Indonesia on 2011-2017. Testing the hypothesis in this study used simple regression. The results of the study show that Good Corporate Governance has a positive effect on financial performance as measured by Return on Assets (ROA), Return on Equity (ROE), Asset growth. On the contrary, Good Corporate Governance has a negative impact on operating expenses and Non-Performing Finance (NPF). At the same time, the effect of Good Corporate Governance toward Islamic Social Responsibility disclosure (ISR) is not significant.
\end{abstract}

Index Terms-. Islamic Social Responsibility, Good Corporate Governance, Financial Performance

\section{INTRODUCTION}

Good Corporate Governance (GCG) arises as a solution to agency problems. Agency theory argues that management does not always act in the best interest of shareholders and that shareholders can monitor management behaviour (Jensen and Meckling, 1976). Moreover, corporate governance aims to solve conflicts between shareholders and management (Buallay, 2019). Based on the survey conducted by CLSA (2001), it shows that GCG is closely related to company performance. Companies that are ranked in the top 100 in implementing corporate governance or around $20 \%$ have very good financial ratios and have a high level of stock prices, compared to companies that do not apply GCG much higher. This conclusion is in line with the opinion of Klapper and Love (2002), which states that better CG will correlate with higher operating performance. In addition to financial performance, non-financial performance such as Corporate Social Responsibility (CSR) is important, where companies integrate social and environmental interests in operating businesses and interactions with stakeholders (Mosaid, 2012).

In the context of Islam, the first and most important goal in the report of Islamic financial institutions is to show that the company's operations are in line with sharia principles. (Haniffa, 2002). The concept of Islamic Social Responsibility (ISR) is based on the relationship of responsibility to Allah SWT, to humans and respond to the surrounding environment. Each person is obliged to make all his life activities as a form of perfect devotion to God, on the other hand, humans are entrusted to regulate this nature

Revised Manuscript Received on December 30, 2019.

Lela Hindasah, UniversitasMuhammadiyah Yogyakarta, Indonesia (Email: lela.hindasah@gmail.com)

Edi Supriyono, UniversitasMuhammadiyah Yogyakarta, Indonesia (Email: edi.supriyono@umy.ac.id) to improve human relations with humans and human relations with other creatures created by Allah, such as animals, plants and the surrounding environment. Based on this, human beings have two main tasks, namely, to become obedient servants to Allah SWT and to be fair and valid, capable of preserving human life and the natural environment.

Bank had two organisational goals, namely, financial and social (Bachiller and Lacalle, 2018). Corporate governance plays an important role to enhance the financial and social performance (Saeed et al, 2018). Several previous studies found a positive relationship between corporate governance and company performance and ISR..the Research by Black et al. (2003); Klapper and Love (2002) show that corporate governance has a positive effect on company performance. The research conducted by Buallay (2017) shows that shari'a governance significantly influenced the ROA and ROE. Almutairi and Quttainah (2017), found that large corporate boards and large SSBs are more efficient in dealing with different monitoring and advisory roles than small SSBs. Increasing the size of corporate boards and shariah supervisory boards (SSBs) should improve monitoring and advisory functions, management behaviour and organisation performance. Mardnly et al. (2018) analyse the effect of aggregate corporate governance index (i.e. board of directors, audit, disclosure and ownership structure) to firm performance (Earning per share and ROA). The research found that ownership structure is positive and significant on firm performance. The contrast, Ajili and Bouri (2018) found that good corporate governance had an insignificant association with high performance in GCG. Temesgen (2013), found that Good corporate governance namely a large board size tends to impact performance negatively. Furthermore, Al-Tamimi (2012) found an insignificant relationship between GCG practices and performance.

Research related to Good Corporate Governance associated with spatial and ISR shows inconsistent results. The Influence of Corporate Governance on ISR as Farook and Lanis (2005), Abdullah et al. (2011), Haniffa and Cooke (2005) have shown that Islamic governance scores have a positive effect on Islamic social responsibility disclosure, but Rosiana et al. (2015) shows that Corporate Governance Index has no significant effect on ISR. Bachiller and Lacalle (2018) found that greater money allocation to social programs resulted in higher profitability, which can be explained by competitive advantages, reputation and customer satisfaction. Furthermore, an association between corporate governance and social responsibility show that a 


\section{Good Corporate Governance Islamic Social Responsibility, and Firm Performance}

positive significant. Evidence suggests that good govenance leads to good CSR performance (Stuebs and Li Sun, 2015). The diversity of previous research results makes the writers interested in conducting a research related to the effect of GCG to financial performance and Islamic Social responsibility in the sharia banks.

\section{LITERATUR REVIEW AND HYPOTHESIS}

Corporate governance is important to a firm's performance. Mush of research how corporate governance mechanisms affect financial reporting and performance (stuebs and $\mathrm{Li} \mathrm{Sun}, 2015$ ). Corporate governance is concerned about balancing between economic and social goals and between individual and communal goals. Corporate governance encourages the efficient use of resources and equally to require accountability for the to align as nearly as possible the interests of individuals, corporations and society (word bank, 2000). The definition of Corporate Governance is the private and public institutions, including laws, regulations and accepted business practices, which together govern the relationship, in a market economy, between corporate managers and entrepreneurs (OECD, 2001). Good Corporate Governance refers to the mechanism, processes and relations by which corporations are controlled and directed (Narwal, Pathneja, 2016). Based on the agency theory, the objective of corporate governance practices is to minimise the conflict of interests between the management and the shareholders to create and improve shareholders' wealth (Buallay, 2017). The factor that affects the agency problem is unsymmetry information.Agents have a better ability to control the company than the principal. The agents are more directly involved in the management of the company, while the principal is the party that delegates the task to the agent so that it is not directly involved in the management activities of the company. The greater the information asymmetry, it will be difficult for the principal to control the actions taken by the agent.

Good corporate governance can overcome these inconsistencies in interests. The latest development proves that management is not enough to complete the management process to run efficiently, but new instruments are needed, good corporate governance (GCG) to ensure management runs well. GCG is needed to encourage an efficient, transparent and efficient market with regulations. Corporate governance is concerned with maximisation of the common interests of a network of factor that interface with operations, organisation, objectives and goals of a corporation (Choudhury and Alam, 2013). The governance of sharia bank is different from their conventional. Syariah bank must undertake their activities only based on shariah law (Grassa and Matoussi, 2014)

Implementation of Good Corporate Governance in Islamic banks is based on 5 basic principles (Hamdani,2016) as:

1. Transparency is openness in gathering material and relevant information and openness in the decision-making process stewardship of those resources. Corporate governance aims

2. Accountability is the clarity of functions and implementation of bank organ accountability so that management runs effectively

3. Responsibility is the suitability of bank management with applicable laws and regulations and the principles of sound bank management

4. Professionals are having competence capable of acting objectively and free from influence or pressure from any party (independent) and having a high commitment to developing Islamic banks

5. fairness is justice and equality in fulfilling the rights of stakeholders based on agreements and applicable laws and regulations Banks are required to implement GCG in each of their business activities at all levels or levels of the organization. In an effort to improve and improve the quality of GCG implementation. Banks are required to periodically conduct a comprehensive self -assessment of the adequacy of GCG implementation.

If there are still shortcomings in its implementation, the bank immediately implements the necessary corrective measures self -assessment of GCG implementation is carried out on Islamic banks based on Bank Indonesia Circular Letter No 12/13 / DPbs / 2010, namely: An evaluation of the implementation of GCG for Islamic banks is carried out on the following 11 factors:

1. Implementation of the duties and responsibilities of the board of commissioners

2. Implementation of duties and responsibilities of directors

3. Completeness and implementation of committee duties

4. Implementation of the duties and responsibilities of the sharia supervisory board

5. Implementation of sharia principles in the activities of raising funds and financing and services

6. Handling of sharia principles in fundraising activities and fund distribution and service services

7. Application of the compliance function

8. Application of the internal audit function

9. Application of the external audit function

10. Maximum limit of funding

11. Transparency of sharia banking financial and nonfinancial conditions, GCG implementation reports and internal reporting

\section{Islamic Social Responsibility}

The theories that are often used in CSR include legitimacy theory and stakeholder theory. Legitimacy theory is a theory which states that CSR is the answer to the surrounding environment related to social, political and economic pressures. According to this theory, companies are trying to find a balance point in running their business with the wishes of the surrounding community. Public perception of the company is very important and can affect the company. Stakeholder theory is the most referenced theory in research. This theory refers to the opinion that the company is systematically responsible for all parties involved in the company. A company that is socially 
responsible based on the extent to which decisions made by management pay attention to the interests of stakeholders other than shareholders. Stakeholder theory can be divided into 2, namely primary stakeholders and secondary stakeholders. Primary stakeholders are groups which if they of primary stakeholders are shareholders, managers, users and government. Dependence between primary stakeholders and companies is very vital to the existence of companies in carrying out business activities. Secondary stakeholders are stakeholders who do not have a direct relationship with the company, but their existence can have a positive or negative effect on the company's activities. Examples of secondary stakeholders such as the media. CSR activities with a stakeholder theory approach are ensuring that companies are socially responsible to corporate stakeholders, both primary and secondary stakeholders (Yusuf, 2017).

Islamic Social Reporting Index is the development of social responsibility disclosures which are by sharia principles. Islamic Social Reporting Index as a benchmark for the implementation of social performance of a sharia banking set by AAOIFI which contain compilation of CSR standard items which are used as material for the development of further research on the discussion of CSR items for Islamic Banking (Othman et al, 2009).

The difference between CSR and ISR is that the ISR concept is part of a sharia framework based on law and provisions in accordance with Islamic Shari'a which later became the basis for the emergence of ethical concepts in Islam. which in it regulates and explains human relations with Allah SWT, human relations with humans, and human relations with the universe. While the concept of CSR is closely related to the goal of achieving sustainable economic activity. The sustainability of economic activities is not only related to the issue of social responsibility but also concerns the accountability of the company to the community and the nation and the international world (Khoirudin, 2013).

Information disclosure for the purpose of decisions in the economy and religion to fulfill obligations to God and society. That is what distinguishes CSR in the Islamic concepts of Haniffa and Hudaib (2002). CSR activities in Islam are not just carrying out law orders or responsibilities to the community or to get views from the community so that they get greater profits. CSR activities rely on spiritual values for the responsibility of Allah's command. The implementation of Islamic CSR has a philosophical value based on Al-Quran and Assunnah, then becomes a guideline in various life activities, not least in the implementation of CSR towards companies that are built on Islamic values.

Some researchers try to develop an Islamic Social Reporting index that is more adapted to the concept of sharia accounting with the aim of increasing accountability and transparency especially in companies registered in sharia securities. This instrument is expected to help investors in making better religious-economic decisions (Haniffa, 2002). One of the researchers who developed the Islamic Social Reporting index was Haniffa (2002).

Haniffa (2002) developed Islamic Social Reporting based on three dimensions of sharia that are interrelated, namely: are not involved in a sustainable manner will have a negative impact on the company for a long time. Examples gaining the Grace of Allah SWT as the main goal in

realizing socio-economic justice, providing benefits to the community in order to fulfill the obligations of society and achieve prosperity to meet individual needs. Based on these objectives, Haniffa (2002) developed the scope of disclosure of Islamic Social Reporting (ISR) which is limited to 5 themes, namely: finance and investment, products, employees, society and the environment.

Othman et al. (2009) developed an index instrument belonging to Hanifa (2002) into 6 themes which contained items in the index of disclosure of Islamic Social Reporting, adding the theme of corporate governance which was considered important because it could ascertain whether companies adhere to sharia principles and not conduct activities / transactions that violate sharia principles. Regarding the theme of corporate governance, companies must disclose all prohibited activities, such as monopolistic practices, stockpiling of basic materials, price manipulation, gambling and all activities that violate the law.

\section{Hypothesis}

This research uses 5 measure of financial performance (i.e Return on Asset, Return on Equity, Eficiency operational, growth and Non-Performing Financing) and 1 measure of social performance (ISR).

The company's management is the business wheel that drives the company in the search for profit. The success can be achieved by the implementation of the principles of GCG as a whole. Implementation of GCG mechanism governance has the purpose of giving progress to the performance of a company, one of which is the profitability of the company. Thus, the implementation of GCG principles can improve the profitability of the company due to the success of the performance achieved.

According to research conducted by Buallay (2017) shows that shari'a governance significantly influenced the ROA and ROE. Almutairi and Quttainah (2017), found that large corporate boards and large SSBs are more efficient in dealing with different monitoring and advisory roles than small SSBs. Mardnly et al (2018) found that ownership structure is positive and significant on firm performance.

Efficiency operational ratio is the ratio between operational cost and operating income. The purpose of the Efficiency operational ratiois to measure the efficiency of operational activities of Sharia banks. Some benefits that can be gained by implementing corporate governance based on Forum for Corporate Governance in Indonesia (2001), among others, are to improve the performance of the company through the creation of better decision-making process, to improve the operational efficiency of the company and to improve the service to stakeholders.

Based on the description, it can be concluded that the implementation of GCG can improve the operational efficiency of the company, including in it is the operational cost efficiency incurred by the company in its activities.

The implementation of GCG can increase the customers' trust to save their funds or to finance the bank. On the other hand, according to the Forum for the Corporate Governance

Published By: 


\section{Good Corporate Governance Islamic Social Responsibility, and Firm Performance}

in Indonesia (FCGI) (2001), the benefits that can be gained through the implementation of corporate governance are, among others, further improving services to stakeholders, thereby enabling GCG implementation to increase customer confidence in saving or financing at banks.

Non-Performing Financing (NPF) is the ratio between non-performing financing on total financing disbursed. The higher this ratio indicates that the quality of financing in banks is getting worse. Basically, the bank has an intermediary function between the party who needs the funds and the one which has excess funds. Distribution of funds from banks is expected to minimize the risk of failure of loan repayment. Given the principle of good corporate governance, banks become more careful in financing. The existence of GCG principles is important, as this principle will assist the bank in carrying out the existing principles and be able to guarantee the rate of return borrowed and provide the maximum profit for the bank (Surya and Yustiavandana, 2008). Implementation of GCG principles to the banking world is closely related to the Financing to be provided by banks to prospective borrowers by prioritizing prudential principles. Thus, when banks implement GCG, the level of problem in financing will decrease, due to the application of prudential banking of banks in disbursing funds (Pratiwi, 2016).

Research related to Good Corporate Governance associated with spatial and ISR shows that Islamic governance scores have a positive effect on Islamic social responsibility disclosure (Farook and Lanis, 2005; Abdullah et al. 2011; Haniffa and Cooke,2000). Bachiller and Lacalle (2018) found that greater money allocation to social programms resulted in higher profitability, which can be explaned by competitive advantages, reputation and customer satisfaction. Futhermore association between corporate governance and social responsibility show that a positive significan. Stuebs and Li Sun (2015) suggests that good govenance leads to good CSR performance.

Based on the stated purpose, the literature review, and research questions, the following hypotheses are formulated:

H5 GCG implementation has a negative effect on NPF ratio.

H1 GCG implementation has a positive effect on ROA.

H3 GCG implementation has a positive effect on ROE

H3 GCG implementation has a positive effect on Growth

H4: GCG implementation has negative effects on efficiency operational

H5 GCG implementation has a negative effect on NPF

H6 GCG implementation has a positive effect on ISR

\section{RESEARCH METHOD}

\section{Population}

The objects of this research are sharia bank that implements Good Corporate Governance (GCG), with the observation samples period starting from 2011 to 2017.
Table 1

The object of this research

\begin{tabular}{|c|c|c|}
\hline $\begin{array}{l}\mathrm{N} \\
\mathbf{0}\end{array}$ & $\begin{array}{l}\text { Notat } \\
\text { ion }\end{array}$ & Measurement \\
\hline 1 & GCG & $\begin{array}{l}\text { Based on self assessment Good Corporate } \\
\text { Governance index }\end{array}$ \\
\hline 2 & ROA & $R O A=\frac{\text { Income after } T a x}{\text { Total Asset }} x 100 \%$ \\
\hline 3 & ROE & $R O A=\frac{\text { Income after Tax }}{\text { Total Equity }} \times 100 \%$ \\
\hline 4 & $\begin{array}{l}\text { BOP } \\
0\end{array}$ & BOPO $=\frac{\text { Total Operating Cost }}{\text { Total Operating Income }} \times 100 \%$ \\
\hline 4 & $\begin{array}{l}\text { GRO } \\
\text { WTH }\end{array}$ & BOPO $=\frac{\text { Total Asset } t-\text { Total Asset } t-1}{\text { Total Total Aset } t-1} \times 100 \%$ \\
\hline 5 & NPF & $N P F=\frac{\text { Non Performance Financing }}{\text { Total Financing }} \times 100 \%$ \\
\hline 6 & ISR & $\begin{array}{l}\text { The development of the index from Othman and } \\
\text { Thani (2009). ISR based on five themes: finance } \\
\text { and investment, product, employees, society and } \\
\text { environment. The approach to scoring items is } \\
\text { essentially dichotomous in that an item in the } \\
\text { research instrument scores one if disclosed and } \\
\text { zero if it is not }\end{array}$ \\
\hline
\end{tabular}

\begin{tabular}{|c|c|c|c|c|c|c|c|}
\hline & \multicolumn{7}{|c|}{ Year } \\
\hline & 2011 & 2012 & 2013 & 2014 & 2015 & 2016 & 2017 \\
\hline $\begin{array}{c}\text { Syaria } \\
\text { Bank }\end{array}$ & 11 & 11 & 11 & 12 & 12 & 13 & 13 \\
\hline $\begin{array}{c}\text { Incomplete } \\
\text { data }\end{array}$ & $(3)$ & $(0)$ & $(0)$ & $(1)$ & $(0)$ & $(1)$ & $(2)$ \\
\hline $\begin{array}{c}\text { Numbers of } \\
\text { bank }\end{array}$ & 8 & 11 & 11 & 11 & 12 & 12 & 11 \\
\hline Total & \multicolumn{7}{|c|}{76} \\
\hline
\end{tabular}

Based on table 5.1, the sample of companies in 2011 was 8 companies, in 2012 there were 11 companies, in 2013 there were 11 companies, in 2014 there were 11 companies and in 2015 there were 12 companies, in 2016 there were 12 companies, in 2017 there were 11 companies. This study uses panel data with a total data of 76 .

\section{Variables and Variables Measurement}

In this research, we use Good Corporate Governance (GCG) as an independent variableand 6 dependent variables; Return on Asset (ROA), Return on Equity (ROE), Operational Efficiency Ratio (OPR) PertumbuhanAset (GROWTH), Non Performing Loan (NPF), and Islamic Social Responsibility (ISR). The measurement of each variable is as follows:

\section{DATA ANALYSIS AND DISCUSSION\& RESULTS}

\section{A. Descriptive statistic}

Tabel 2

Descriptive statistic

\begin{tabular}{|c|c|c|c|c|c|}
\hline & $\mathrm{N}$ & Minimum & Maximum & Mean & SD \\
\hline ROA & 76 & $-0,2013$ & 0,1120 & 0,2128 & 0,2375 \\
\hline ROE & 76 & $-0,5864$ & 0,5798 & 0,0078 & 0,0378 \\
\hline GROWTH & 76 & $-0,2883$ & 1,1012 & 0,0536 & 0,1667 \\
\hline OPREX & 76 & 0,4760 & 1,9269 & 0,9317 & 0,2086 \\
\hline
\end{tabular}




\begin{tabular}{|l|l|l|l|l|l|}
\hline NPF & 76 & 0,0000 & 0,0493 & 0,0219 & 0,0158 \\
\hline ISR & 76 & 0,3188 & 0,6957 & 0,5118 & 0,0951 \\
\hline
\end{tabular}

Independent variable used in this research is Good Corporate Governance (GCG). The dependent variables are Return on Assets (ROA), Return on Equity (ROE), GROWTH, Operational Efficiency Ratio (BOPO), NonPerforming Finance (NPF) and ISR..

\section{B. Data analysis and discussion}

\section{Table 3}

Estimated coefficients for ROA, ROE, GROWTH, NPF, EFOPR, ISR

The effect of GCG toward Profitability showed that the quality of the GCG application had a significant positive effect on Profitability ratio (ROA and ROE). The implementation of good GCG mechanism causes the company to increase its assets. Good management can encourage the effectiveness of the use of company assets and improve the ability of banks in obtaining net income, to increase the profitability ratio of the bank. The result of the research is in accordance with Black et al., (2003); Klapper and Love (2002Buallay (2017) Almutairi and Quttainah (2017), and. Mardnly et al. (2018) found that ownership structure is positive and significant on firm performance.

GCG has a significant negative effect on EFOPR ratio in Sharia bank. Efficiency operational ratio is the ratio between operational cost and operating income. The purpose of the EFOPR ratiois to measure the efficiency of bank operations. The implementation of good corporate governance encourages the performance of the company to work more efficiently, including improving the operational efficiency of the company's activities, in accordance with the Forum for the Corporate Governance in Indonesia (FCGI) (200), which states that the benefits of GCG can improve the company's performance through the creation of the process of making better decisions, and improve the operational efficiency of the company.

The quality of GCG implementation has a positive effect on Growth Asset to Sharia commercial banks. The implementation of GCG can increase the customers' trust to save their funds or to finance the bank. According to the Forum for the Corporate Governance in Indonesia (FCGI) (2001), the benefits that can be gained through the implementation of corporate governance are, among others, further improving services to stakeholders, thereby enabling GCG implementation to increase customer confidence in financing at banks.

The result of hypothesis test 5 shows that the quality of GCG implementation has a significant negative effect on

\begin{tabular}{|c|c|c|c|c|c|c|}
\hline Independent & \multicolumn{6}{|c|}{ Dependent Variables } \\
\hline & ROA & ROE & GROWTH & NPF & EFOPR & ISR \\
\hline Constant & $\begin{array}{l}-0,069 \\
(0,013)^{* * *}\end{array}$ & $\begin{array}{l}-0,332 \\
(0,006) * k * k\end{array}$ & $\begin{array}{l}-0,46 \\
(0,005) \text { *k*k.k. }\end{array}$ & $\begin{array}{l}0,043 \\
(0,000)^{\text {*kak }}\end{array}$ & $\begin{array}{l}1,342 \\
(0,000)^{\text {*k*k* }}\end{array}$ & $\begin{array}{l}0,472 \\
(0,000)\end{array}$ \\
\hline GCG & $\begin{array}{l}0,025 \\
(0,005)^{* * * k * k}\end{array}$ & $\begin{array}{l}0,124 \\
(0,001)^{\text {*k k k }}\end{array}$ & $\begin{array}{l}0,217 \\
(0,000)^{\text {k*k*k }}\end{array}$ & $\begin{array}{l}-0,007 \\
(0,065)^{*}\end{array}$ & $\begin{array}{l}-0,0132 \\
(0,007)^{* k * k *}\end{array}$ & $\begin{array}{l}0,013 \\
(0,573)\end{array}$ \\
\hline R Square & $10 \%$ & $13,2 \%$ & $19,8 \%$ & $4,5 \%$ & $9,5 \%$ & $0,4 \%$ \\
\hline F Statistic & 8,275 & 11,229 & 18,264 & 3,505 & 7,779 & 0.321 \\
\hline $\begin{array}{l}* \operatorname{Sig} 10 \% \\
* * \operatorname{sig} 5 \% \\
* * * \operatorname{sig} 1 \%\end{array}$ & & & & & & \\
\hline
\end{tabular}

NPF ratio in Sharia bank. The bank is an institution that prioritises the prudential principle in financing and the occasional evaluation of risk management to minimise the level of problem financing. Bank Indonesia Regulation in the implementation of GCG requires Syariah bank to have a Risk Management Committee and Risk Management Unit, which in theory can reduce the risk of financing arising. It is reinforced by internal and external audit function, which also reduces financing risk in Syariah bank (Syam and Nadja, 2012). This means that the indicators set by Bank Indonesia in the implementation of GCG can reduce the problematic financing that arises in the Syariah Bank. The result of the research is by Pratiwi's (2016) study, which shows that the quality of GCG implementation affects NPF ratio.

The result of the last hypothesis shows that GCG has an insignificant effect on ISR. GCG a positive effect on financial performance but not significant effect on social performance (ISR).

\section{CONCLUSION}

This study examines corporate governance on the performance of Sharia Bank in Indonesia. We investigate the performance of Syaria bank two-fold, financial performance (ROA, ROE, GROWTH, EFOPR, NPF) on one hand and social performance (ISR) on the other hand). The data collected were pooled data from an annual report Bank in Indonesia during the period 2011-2017. Good Corporate Governance has a significant effect on performance (ROA, ROE, GROWTH, EFOPR, NPF). Good Corporate Governance variable is proven to increase performance and can make Sharia Commercial Bank more efficient in its operational activities but Good Corporate governance is not proven to significantly affect social performance (ISR). This study contributes to the existing literature of the governance of sharia bank. The infortance of Good corporate Governance for financial and social performance is separately discussed. The motivation of the research is to find out haw Syaria Bank can have achieved their financial and social performance with the help of corporate governance action.

\section{REFERENCES}

1. Abdulllah. T dan Billy A.N, 2011, Determinankualitasimplementasi corporate governance padaperusahaan yang terdaftar di Bursa Efek Indonesia (BEI) periode 2004-2008, JurnalPendidikanAkuntansi Indonesia Vol IX No 1 Tahun 2011, hlm 1-23

2. Ajili, H., A. Bouri, "Corporate governance quality of Islamic bank: measurement and effect on financial performance," International journal of Islamic and middle eastern finance and management, vol. 11 no.3, 2018, pp 591-607

3. Almutairi A. R. and M. A. Quttainah, "Corporate Governance: evidence from Islamic Banks" Social Responsibility Journal, vol 13 No.3, pp 601-624, 2017

4. Al-Tamimi, H. A. H., "The effect of corporate governance on performance and financial distress," Journal of financial regulation and compliance, vol 20 no 2, pp 169-181, 2012

5. Bachiller P. and J.G. Lacalle, Corporate governance in Spanish saving banks and its relationship with financial and social performance', Management decision vol 56 no. 4, pp 828-848, 2018 
6. Black, B., H. Jang, W. Kim, 2002, Does Corporate Governance Affect Firm Value? Evidence from Korea, Stanford Law School, Working Paper, November, 2002

7. Buallay A., "Corporate governance, sharia'ah governance and performance,"international Journal of Islamic and Middle Eastern Finance and Management Vol 12 No. 2, pp 216-235, 2019

8. Choudhury, M. A. and Alam, M.N, "Corporate governance in Islamic perspective," International Journal of Islamic and Management, vol. 6 no. 3 pp. $180-199,2013$

9. Hamdani, Good Corporate Governance, Mitrawacana Media, Tangerang, Indonesia, 2016

10. Haniffa a, T.E. Cooke b, (2005), The impact of culture and governance on corporate social reporting, Journal of Accounting and Public Policy 24 (2005) 391-430

11. Jensen M. and W. Meckling, "Theory of the firm, managerial behavior, agency costs and ownership structure", Journal of Financial Economics, vol.3 no. 4 pp.305-360, 1976

12. Grassa, R and H Matoussi, "Corporate governance of Islamic bank", Acomparative study between GCG and Southeast Asia countries, 'International journal of Islamic and middle Eastern Finance and management, vol 7 no 3, pp 346-362, 2014

13. Haniffa, Ri, Hudaib, M, (2007), Exploring the Ethical Identity of Islamic Bank via Communication in annual Reports, Journal of Business ethics 76:97-116

14. Khoirudin,A (2013), Corporate Governance danPengungkapan Islamic Social Reporting PadaPerbankanSyariah di Indonesia, Accounting Analysis Journal, AAJ 2 (2), http://journal.unnes.ac.id /sju/index.php/aaj

15. Klapper, L.F. dan I Love., 2003, Corporate Governance, Investor protection and Performance in Emerging Markets. Working PaperThe World Bank

16. Mosaid, F.E ., Boutti, R (2012), Relationship between Corporate Social Responsibility and Financial Performance in Islamic Banking Research Journal of Finance and Accounting, Vol 3, No 10, p 22222847

17. Yusuf MY, (2017), Islamic Corporate Social Responsibility, Kencana, Indonesia

18. Mardnly, Z., S. Mouselli, R. Abdulraouf, "Corporate governance and firm performance: an empirical evidence from Syria," International journal of Islam, vol $11 \mathrm{n} 0.42018$

19. Narval K. P and S Pathneja,"Effect of bank specific and governance specific variabeles on the productivity and profitability of bank", International journal of Productivity and performance management vol.66 no. 8, pp 1057-1074, 2016

20. Nyamongo, E.M and K Temesgen,'The effect of governance on performance of commercial banks ini Kenya: a panel study, corporate governance, vol. 13, no.3 pp 236-248, 2013

21. Othman, R., Thani A.M., (2010), Islamic Social Reporting Of Listed Companies In Malaysia, International Business \& Economics Research Journal - April Volume 9, Number 4

22. Othman, R.A., Thani, Md., Ghani, E.K (2009), Determinants of Islamic Social Reporting Among Top Shariah-Approved Companies in Bursa Malaysia, Research Journal of Internatıonal Studies - Issue 12, 4-20

23. Stuebs, M. and $\mathrm{Li}$ Sun, "Corporate governance and social responsibility;" International journal of law and management, vol 57 no 1, pp 38-52, 2015

24. Saeed A., A. Y. Javed and U Noreen,'Microfinancing, govenance, and performance: asouth Asian perspective", Journal of Economic and Administrative Science, vol. 23 no. 46 pp 247-265, 2018 